\title{
A Field Survey of Sucking Tea Pests and Their Control Measures in a Few Tea Gardens of Terai Region, West Bengal, India
}

\author{
Satyajit Sarkar ${ }^{1}$, S. E. Kabir ${ }^{2}$ \\ Department of Tea Science, University of North Bengal, P.O.: North Bengal University, \\ Raja Rammohanpur, Dist.: Darjeeling,West Bengal, PIN.: 734013
}

\begin{abstract}
A field survey had been carried out from September 2013 to November 2015 in few tea gardens of Terai region, West Bengal. It was found that the sucking pest Tea Mosquito Bag attack was highest in Terai region nearly about 35\% of total pest occurrence. The other sucking pest attack was Red Spider Mite attack near about 20\%, Tea Jassid 12\%, Aphids 10\%, Thrips $7 \%$ of total pest occurrence. The tea gardens of that region uses Tea Research Association (TRA) recommended and Tea Board approved pesticides to control them.
\end{abstract}

Keywords: Tea garden, sucking pest, pest control

\section{Introduction}

Terai region has a good agro climatic condition for tea plantation and large numbers of tea gardens are present in that region. The tea growing environment also include a huge number of sucking tea pests. It causes huge crop loss and detoriated the quality of tea. In Terai region mostly Tea Mosquito Bag (Helopeltis thevora), Tea Thrips (Scirtothrips dorsalis), Tea Jassid (Empoasca flavescens), and Aphids
(Toxoptera aurantii) are observed. Red spider mite (Oligonychus coffeae) also suck the sap of mature tea leaves although it has other activities.To control these sucking tea pests wide varieties of pesticides are used in different tea gardens as per recommendations of Tea Research Association (TRA). Sucking tea pests are controlled in three different ways as chemical control, biological control and cultural control (Borthakur and Singh, 2002).

Table 1: Sucking tea pests (Kabir and Das, 2015)

\begin{tabular}{|c|c|c|c|c|}
\hline $\begin{array}{c}\text { Name of the sucking } \\
\text { tea pest }\end{array}$ & $\begin{array}{l}\text { Damaging } \\
\text { stage }\end{array}$ & $\begin{array}{l}\text { Seasonal } \\
\text { incidence }\end{array}$ & Site of attack & Damage symptoms \\
\hline \begin{tabular}{|c|} 
Tea Mosquito Bag \\
(Helopeltis thevora)
\end{tabular} & $\begin{array}{c}\text { Nymphs and } \\
\text { Adults }\end{array}$ & $\begin{array}{l}\text { February- } \\
\text { November }\end{array}$ & $\begin{array}{c}\text { Young leaves, buds } \\
\text { and tender stems }\end{array}$ & $\begin{array}{l}\text { Initially, a ring like spot formed at the sap-sucking point } \\
\text { turning translucent light brown within } 24 \text { hours and later it } \\
\text { turns dark brown in color and appear as a sunken spots and } \\
\text { dry up. }\end{array}$ \\
\hline $\begin{array}{l}\text { Tea Thrips } \\
\text { (Scirtothrips } \\
\text { dorsalis) }\end{array}$ & $\begin{array}{c}\text { Nymphs and } \\
\text { Adults }\end{array}$ & March-April & $\begin{array}{c}\text { Unopened or partly } \\
\text { opened buds and } \\
\text { young succulent } \\
\text { leaves }\end{array}$ & \begin{tabular}{|l} 
Leaf surface becomes uneven, curly, matty, showing \\
parallel lines of feeding marks on either side of midrib and \\
2-4 sand papery lines on either side of the midrib.
\end{tabular} \\
\hline $\begin{array}{l}\text { Tea Jassid } \\
\text { (Empoasca } \\
\text { flavescens) }\end{array}$ & $\begin{array}{c}\begin{array}{c}\text { Nymphs and } \\
\text { Adults }\end{array} \\
\end{array}$ & May-July & $\begin{array}{c}\text { Young leaves and } \\
\text { tender stems }\end{array}$ & $\begin{array}{c}\text { The affected leaves become uneven and the leaves curl } \\
\text { downwards. The margin become recurved and } \\
\text { subsequently turns brown and dry up. The midrib and veins } \\
\text { of the affected leaves may show brownish discolouration. }\end{array}$ \\
\hline $\begin{array}{c}\text { Aphids (Toxoptera } \\
\text { aurantii) }\end{array}$ & $\begin{array}{c}\text { Nymphs and } \\
\text { Adults }\end{array}$ & January-April & $\begin{array}{c}\text { Buds, young leaves } \\
\text { and tender stems }\end{array}$ & Crinkled and curled leaves bellow tipping level. \\
\hline $\begin{array}{l}\text { Red Spider Mite } \\
\text { (Oligonychus } \\
\text { coffeae) }\end{array}$ & $\begin{array}{c}\text { Nymphs and } \\
\text { Adults }\end{array}$ & $\begin{array}{l}\text { Almost } \\
\text { throughout the } \\
\text { year }\end{array}$ & Mature tea leaves & $\begin{array}{c}\text { Normally attacks the upper surface of the mature leaves in } \\
\text { case of severe attack it spreads to the undersurface and } \\
\text { young leaves also. Reddish spots developed on the sucking } \\
\text { sites which later on unite to form large brown patches. The } \\
\text { leaves turns ruddy bronze, marking the fields distinct even } \\
\text { from a distance. In case of severe attack leaves may dry up } \\
\text { and fall off. }\end{array}$ \\
\hline
\end{tabular}

\section{Materials and Methods}

1. Study Area: The field study was conducted in tea gardens of Terai regions West Bengal, India. Field surveys were conducted in different tea gardens of the study area. The field surveyed tea gardens are Matigara tea estate, Dagapur tea estate, Sukna tea estate, Mohurgong and Gulma Tea Estate, New Chamta Tea Estate, Simulbari Tea Estate,
Marionbarrie Tea Estate, Kamalpur Tea Estate, Tirihannah Tea Estate and Hansqua Tea Estate.

2. Data Collection: The presented data were collected during field survey of mentioned tea estates during September 2013 to November 2015. During the field survey different sections of mentioned tea gardens were studied and data collected from the office of the gardens. 


\section{International Journal of Science and Research (IJSR) \\ ISSN (Online): 2319-7064 \\ Index Copernicus Value (2013): 6.14 | Impact Factor (2014): 5.611}

\section{Result and Discussion}

During the field study, it was observed that the tea gardens of Terai region mostly affected by Tea Mosquito Bag attack near about 35\% of total pest occurrence. Red Spider Mite attack near about 20\% , Tea Jassid 12\%, Aphids 10\%, Thrips $7 \%$ respectively of total pest occurrence.

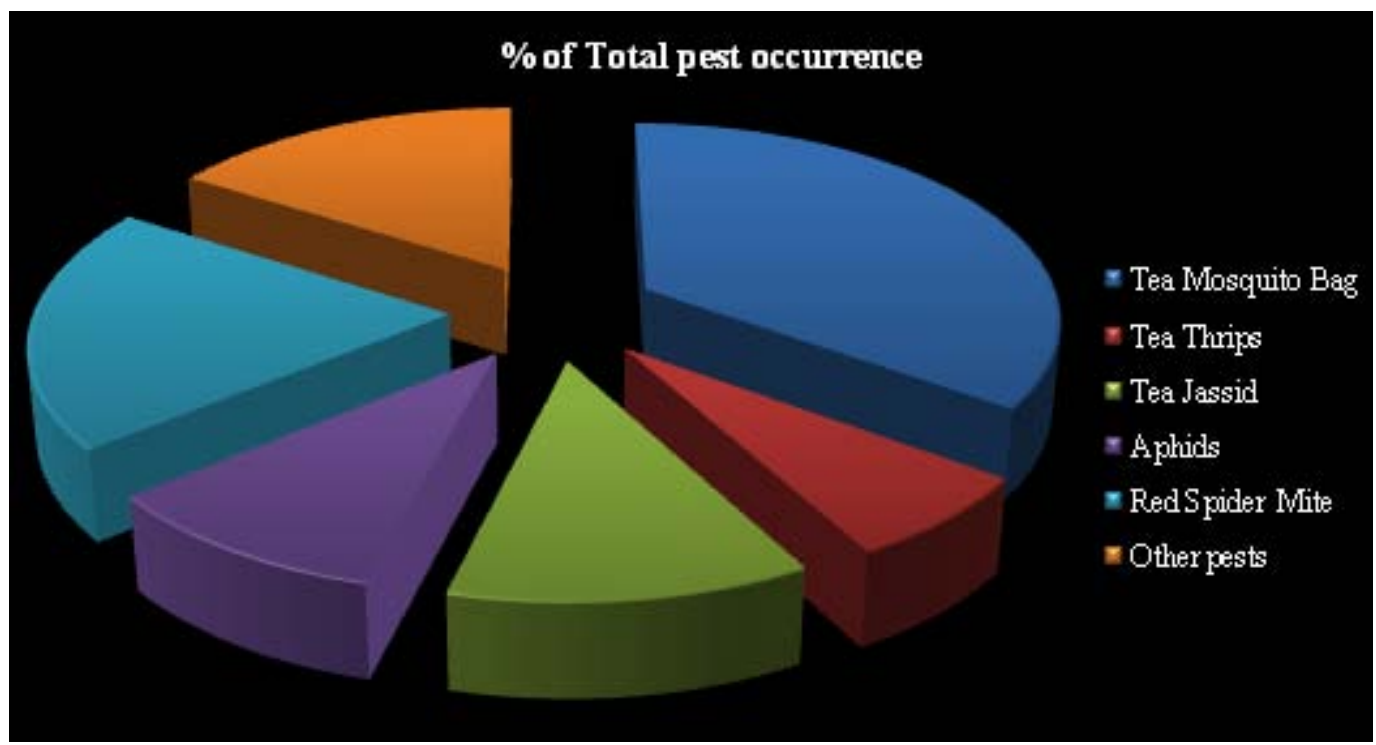

Figure: Percentages of sucking pest attack of total pest occurrence

To control the attack of sucking pests, the tea gardens uses Tea Research Association (TRA) recommended specific pesticides in specific dose. The pesticides are also approved in the Plant Protection Code approved by Tea Board:

\begin{tabular}{|c|c|c|}
\hline Name of the sucking tea pest & Pesticide used & Dose \\
\hline \multirow[t]{2}{*}{ Tea Mosquito Bag } & Thiamethoxam 25\% WG & 50g/200l water/acre \\
\hline & Thiacloprid 21.7\%SC & $150 \mathrm{ml} / 200 \mathrm{l}$ water/acre \\
\hline \multirow[t]{2}{*}{ Tea Thrips } & Thiamethoxam 25\% WG & 50g/200l water/acre \\
\hline & Thiacloprid 21.7\%SC & $150 \mathrm{ml} / 200 \mathrm{l}$ water/acre \\
\hline \multirow[t]{2}{*}{ Tea Jassid } & Thiamethoxam 25\% WG & $50 \mathrm{~g} / 200 \mathrm{l}$ water/acre \\
\hline & Thiacloprid 21.7\%SC & $150 \mathrm{ml} / 200 \mathrm{l}$ water/acre \\
\hline \multirow[t]{2}{*}{ Aphids } & Thiamethoxam 25\% WG & 50g/200l water/acre \\
\hline & Thiacloprid 21.7\%SC & $150 \mathrm{ml} / 200 \mathrm{l}$ water/acre \\
\hline \multirow[t]{4}{*}{ Red Spider Mite } & Hexythiazox 5.45\%EC & $160 \mathrm{ml} / 200 \mathrm{l}$ water/acre \\
\hline & Fenpyroximate 5\% EC & $200 \mathrm{ml} / 200 \mathrm{l}$ water/acre \\
\hline & Propargite 57\% EC & $300 \mathrm{ml} / 200 \mathrm{l}$ water/acre \\
\hline & Fenazaquin 10\% EC & $400 \mathrm{ml} / 200 \mathrm{l}$ water/acre \\
\hline
\end{tabular}
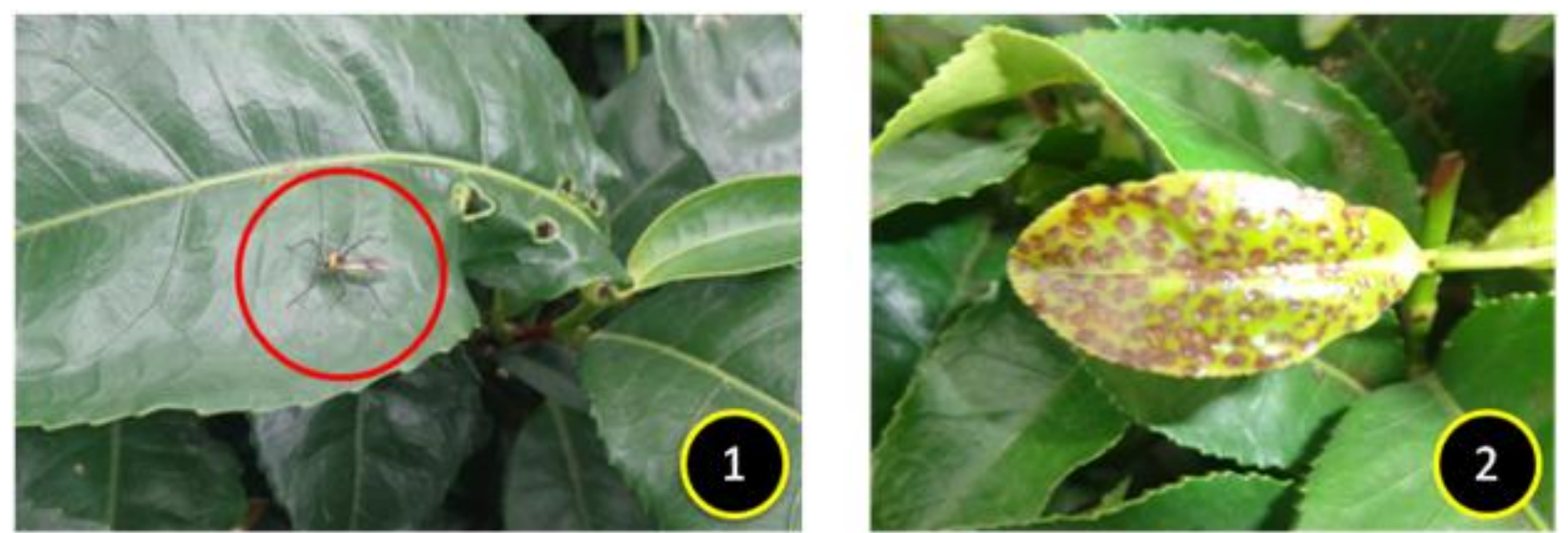


\section{International Journal of Science and Research (IJSR) \\ ISSN (Online): 2319-7064}

Index Copernicus Value (2013): 6.14 | Impact Factor (2014): 5.611

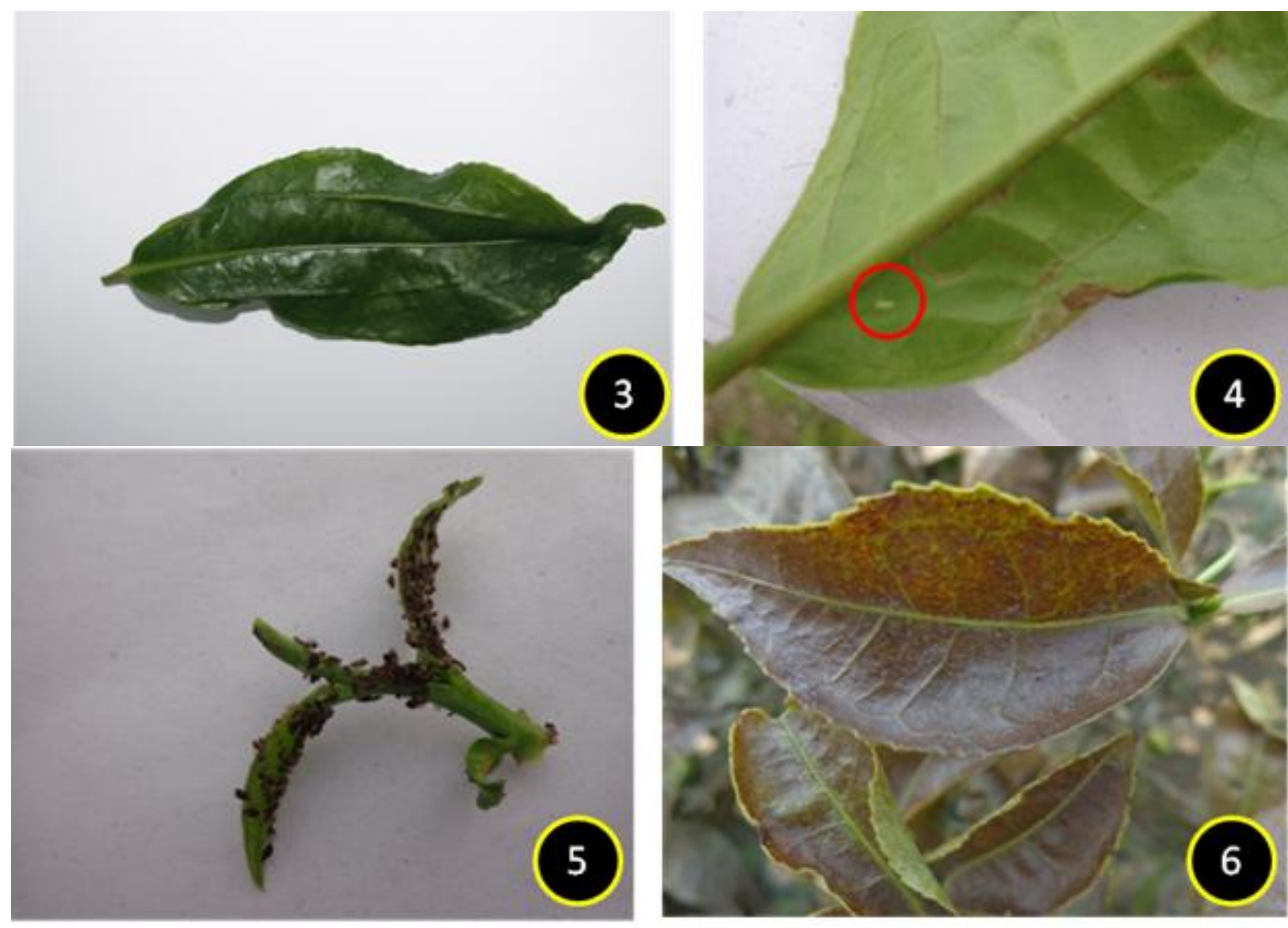

1. Tea Mosquito Bag (Helopeltis thevora), 2. Tea Mosquito Bag affected leaf, 3. Tea Thrips affected leaf, 4. Tea Jassid (Empoasca flavescens), 5. Aphids (Toxoptera aurantii), 6. Red spider mites (Oligonychus coffeae).

\section{References}

[1] Anonymous . (1994). Pest of Tea in North-East India and their control. Tea Research Association. Tocklai Experimental Station. Page no.: 01-208.

[2] Barua, D. N. (2008). Pest and diseases. Science and Practice in Tea Culture. Tea Research Association. Page no.: 545-576.

[3] Borthakur, M. and Singh, K. (2002). Biology and Control of Tea and Shade Tree Pests. Notes on Field Management. Page no.: 171-192.

[4] Kabir, S. E. and Das A. P. (2015). Pest Control. Tea Cultivation in the plains of North East India. Page no.: 154-197.

[5] Muraleedharan, N. (1991). Pest Management in Tea. UPASI- Tea Research Institute. Page no.: 01-118.

[6] Muraleedharan, N. (1993). Ecology and Management of Tea Pests. Tea Culture, Processing and Marketing. Page no.: 129-144.

[7] Singh, I. D. (2005). Plant Protection. The Planter's Guide to Tea Culture and Manufacture. Page no.: 109-153.

[8] Sinha, M. P. (2010). Pest Control in Tea. World Tea Production and Manufacturing. Page no.: 252-273. 